Зінкевич О. В., к.е.н., доцент (Національний університет водного господарства та природокористування, м. Рівне)

\title{
ОБЛІК ОСНОВНИХ ЗАСОБІВ НА ЕТАПІ ЗАВЕРШЕННЯ ЖИТТЄВОГО ЦИКЛУ ІНВЕСТИЦІЙ В НИХ
}

Статтю присвячено розгляду методики обліку основних засобів на етапі завершення інвестицій в них. Проаналізовано існуючий підхід та подано пропозиції щодо відображення таких операцій на бухгалтерських рахунках з урахуванням напрямків та причин вибуття. Сформовано рекомендовану кореспонденцію рахунків. Описано зміни, що торкнуться реквізитів первинних бухгалтерських документів та реєстрів, використовуваних при відображенні господарських операцій з вибуття необоротних активів та їх наступного повернення.

Ключові слова: основні засоби, інші необоротні матеріальні активи, вибуття необоротних активів, облік, пере класифікація активів.

Постановка наукової проблеми та її значення. Згідно з національними та міжнародними стандартами бухгалтерського обліку основні засоби, як і інші активи, відображаються в звітності підприємства за умови, що оцінка їх може бути достовірно визначена і очікується отримання в майбутньому економічних вигод, пов'язаних з їх використанням [1; 2]. Тобто припинення надходження економічної вигоди від використання $€$ підставою для виключення їх зі складу таких активів, проте не обов'язково підставою для списання їх з балансу підприємства. Тому питання відображення в бухгалтерському обліку операцій з тимчасового вибуття основних засобів потребує методологічного уточнення.

Аналіз останніх публікацій. Питання бухгалтерського обліку основних засобів $\epsilon$ складовою наукового доробку багатьох вченихекономістів. Теоретичним і практичним розробкам у питаннях організації і методики обліку основних засобів присвячено праці таких вітчизняних і зарубіжних вчених, як В.В. Бабич, М.Т. Білуха, М.І. Бондар, О.С. Бородкін, В.В. Бочаров, Ф.Ф. Бутинець, Г.Г. Герасимович, Л.Д. Гітман, С.Ф. Голов, Г.Г. Кірейцев, В.В. Ковальов, Я.Д. Крупка, М.В. Кужельний, Ю.Я. Литвин, В.Г. Лінник, Ю.І. Осадчий, А.А. Пересада, М.С. Пушкар, В.Я. Саблук, В.Я. Савченко, Я.В. Соколов, В.В. Сопко, М.Г. Чумаченко та ін. Однак спеціальні дослідження щодо визначення мети, завдань, об'єкту, предметної області та обліку основних за- 
собів як об'єктів реального інвестування на різних етапах життєвого циклу, їх впровадження у практику діяльності підприємств $є$ недостатніми, що визначає необхідність подальшого вдосконалення.

Мета дослідження. Метою статті $\epsilon$ розробка пропозицій щодо відображення в бухгалтерському обліку тимчасового вибуття основних засобів.

Виклад основного матеріалу. Під життєвим циклом основних засобів слід розуміти період формування та експлуатації об'єктів основних засобів. У життєвому циклі основних засобів як об'єктів реальних інвестицій виокремлюється низка етапів, що вирізняються сутнісними особливостями:

1) етап планування інвестицій в основні засоби (проектування, створення, укладання договору про придбання, інші форми надходження);

2) етап реалізації інвестицій в основні засоби (введення в експлуатацію або зарахування на баланс, внутрішнє переміщення, амортизація, здача у фінансову оренду, поліпшення, часткова ліквідація, переоцінка, консервація);

3) етап завершення життєвого циклу інвестицій в основні засоби (ліквідація (списання з балансу), перекласифікація у необоротні активи, утримувані для продажу, інші форми вибуття) [3, С. 11271133].

Етап завершення життєвого циклу інвестицій в основні засоби передбачає закриття рахунків, що містять інформацію про вартість об'єктів основних засобів (рахунок 10 «Основні засоби» (далі - рахунок 10), рахунок 11 «ннші необоротні матеріальні активи» (далі - рахунок 11)), про суму нарахованого зносу на дату вибуття (рахунок 13 «Знос (амортизація) необоротних активів» (далі - рахунок 13)), про суму накопиченої дооцінки на дату вибуття (субрахунок 411 «Дооцінка (уцінка) основних засобів») з відповідним відображення доходів, витрат та нерозподіленого прибутку від таких операцій.

Ухвалення рішення щодо остаточного відображення в обліку процесу вибуття основних засобів потребує аналізу напрямків та причин таких дій. Можна виокремити три основних напрямки вибуття основних засобів залежно від того, що є результатом такого вибуття:

1) передача іншим фізичним або юридичним особам;

2) списання (ліквідація);

3) вилучення з господарського процесу.

Крім того, вибуття основних засобів можна розглядати з точки зору отримання економічних вигод інвестором:

- операції, що передбачають отримання економічних вигод; 
- операції, що передбачають втрати від їх здійснення;

- операції, що передбачають призупинення надходження економічних вигод.

Передача основних засобів іншим фізичним або юридичним особам передбачає дії, що призводять або до отримання економічних вигод (передача у фінансову оренду, внесок до зареєстрованого (пайового) капіталу іншого підприємства), або до понесення витрат, пов'язаних з вибуттям активів (безоплатна передача, виявлена нестача в результаті проведення інвентаризації, списання у зв'язку з невідповідністю визнання активами, перекласифікація в необоротні активи, утримувані для продажу тощо).

Списання (ліквідація) основних засобів включає операції, що призводять до понесення витрат, пов'язаних з вибуттям (хоча окремі операції одночасно можуть супроводжуватися отриманням певних вигод, наприклад, оприбуткування матеріальних цінностей, отриманих в результаті ліквідації об'єкта, або отримання інших активів в результаті здійснення операцій обміну).

Вилучення основних засобів з господарського процесу включає операції, що відображають вилучення об'єктів засновниками (результатом є зменшення величини власного капіталу підприємства) або тимчасове вилучення у зв'язку з припиненням випуску продукції, виконання робіт, надання послуг, що здійснювалося з допомогою таких засобів, чи у зв'язку з необхідністю здійснення поліпшення об'єктів, яке потребує тривалого часу (капітальний ремонт, реконструкція тощо).

Інструкцією про застосування Плану рахунків бухгалтерського обліку активів, капіталу, зобов'язань та господарських операцій підприємств і організацій (далі - Інструкція № 291) [4] передбачено застосування ряду рахунків, що відображають доходи та витрати, які виникають у результаті здійснення першої та другої груп операцій, проте не відображено застосування рахунків, пов'язаних з тимчасовим вилученням з господарського обороту. Оскільки такі господарські ситуації передбачають призупинення процесу нарахування амортизації, то облік тимчасово вилучених активів не може відображатися на рахунках 10 і 11, залишки по яких показують вартість активів, введених в експлуатацію, а значить таких, що амортизуються (крім земельних ділянок, природних ресурсів та капітальних інвестицій). Вважаємо, що набагато простіше відслідковувати правильність і своєчасність припинення процесу нарахування амортизації, якщо такі активи будуть обліковуватися на рахунку 18 «Довгострокова дебіторська заборгованість та інші необоротні активи» (далі - 
рахунок 18) (за балансовою вартістю). Звичайно це додає роботи обліковим працівникам, проте дозволить чітко розмежовувати об'єкти амортизації і відповідає принципу превалювання змісту над формою при формуванні фінансової звітності.

Крім того, згідно з вимогами національного положення (стандарту) бухгалтерського обліку 1 «Загальні вимоги до фінансової звітності» (далі - НП(С)БО 1) актив відображається у балансі за умови, що оцінка його може бути достовірно визначена і очікується отримання в майбутньому економічних вигод, пов'язаних з його використанням. Тому, якщо актив (об'єкт основних засобів) не відповідає умовам, вказаним у Положенні (стандарті) бухгалтерського обліку 7 «Основні засоби» (далі - П(С)БО 7) - не утримується з метою використання їх у процесі виробництва або постачання товарів, надання послуг, здавання в оренду іншим особам або здійснення адміністративних і соціально-культурних функцій, а очікуваний термін його використання перевищує календарний рік (або операційний цикл, якщо він більший за рік) - але відповідає вимогам НП(С)БО 1, його оприбуткування також може здійснюватися на рахунок 18 за відповідною вартістю (первісною чи справедливою в залежності від шляху надходження активу на підприємство), за умови що цей актив не планується реалізувати. Тому ми не підтримуємо думку А.М. Должанського, О.М. Сістук про доцільність запровадження додаткових субрахунків до рахунків 10, 11 для нагромадження інформації процесу консервації необоротних активів [5, С. 80-82].

Об'єкти основних засобів, що знаходяться в стані реконструкції, модернізації, добудови, дообладнання і консервації, на цей період можуть виключатися зі складу основних засобів і враховуватися, на нашу думку, як інші необоротні активи (рахунок 18) (кореспонденцією дебет рахунку 18 кредит рахунків 10, 11 у сумі залишкової вартості на дату початку реконструкції, модернізації). Амортизація в цей період не нараховується. Переведення об'єктів із інших необоротних активів в основні засоби здійснюється на дату початку їх експлуатації (дебет рахунків 10, 11 кредит рахунку 18). По закінченні вказаних робіт, вартість яких відображають за дебетом рахунку 15 «Капітальні інвестиції», вони також списуються в дебет рахунків 10,11.

Інструкцією № 291 [4] передбачено, що рахунок 18 призначено для обліку дебіторської заборгованості фізичних та юридичних осіб, яка не виникає в ході нормального операційного циклу та буде погашена після дванадцяти місяців з дати балансу, для обліку активів, використання яких, як очікується, неможливо протягом дванадцяти місяців з дати балансу, а також для обліку інших необоротних активів, які не знайшли безпосереднього відображення на інших рахун- 
ках обліку необоротних активів. Таким чином, виключення законсервованих об'єктів основних засобів або об'єктів, що тимчасово вилучені з господарського обороту, із складу активів, облік яких здійснюється на рахунках 10, 11 є вірним тому, що такі об'єкти: 1 - не використовуються у процесі виробництва або постачання товарів і послуг, 2 - не придатні для надання в оренду іншим особам, 3 - не можуть бути використані для здійснення адміністративних і соціальнокультурних функцій. Однак, такі основні засоби не можуть бути виключені зі складу активів - ресурсів, контрольованих підприємством в результаті минулих подій, використання яких, як очікується, приведе до надходження економічних вигод у майбутньому, - оскільки після завершення певних подій (завершення процесу поліпшення) або в результаті виникнення інших умов (розширення або переорієнтація обсягів діяльності, а відповідно повторне залучення в господарську діяльність раніше вилучених об'єктів), вони знову приноситимуть економічну вигоду підприємству. Таким чином, розглянуті випадки можна розглядати як перекласифікацію об'єктів необоротних активів: рахунок 18 накопичує інформацію про вартість активів, що не амортизуються, оскільки облік відображуваних на ньому активів не регламентується вимогами П(С)БО 7.

Вказані зміни знайдуть своє відображення і у кореспонденції рахунків з рахунком 18. Необхідно виключити зі складу рахунків, кореспондуючих 3 кредитом рахунку 18 рахунок 14 «Довгострокові фінансові інвестиції», або включити його і до складу рахунків, що кореспондують з дебетом рахунку 18 (зміст операцій буде аналогічним операціям з поточними фінансовими інвестиціями).

Запропонований варіант обліку передачі/повернення основних засобів на поліпшення чи консервацію відображено у таблиці 1.

Таким чином, у питаннях відображення в обліку операцій з вибуття основних засобів на етапі завершення життєвого циклу інвестицій в основні засоби не спостерігається суттєвих суперечностей, окрім питань відображення об'єктів, що потребують поліпшення чи знаходяться на консервації. Результати проведеного аналізу обліку стану та руху основних засобів підприємства вплинуть на показники первинного, аналітичного та синтетичного обліку підприємства. 
Пропонована кореспонденція рахунків бухгалтерського обліку поліпшення та консервації основних засобів

\begin{tabular}{|c|c|c|c|}
\hline \multirow[t]{2}{*}{$\begin{array}{l}\text { № } \\
3 / \pi\end{array}$} & \multirow[t]{2}{*}{ Зміст господарської операції } & \multicolumn{2}{|c|}{$\begin{array}{l}\text { Кореспонденція } \\
\text { рахунків }\end{array}$} \\
\hline & & Дебет & Кредит \\
\hline \multirow[t]{3}{*}{1.} & \multicolumn{3}{|c|}{$\begin{array}{l}\text { Відображення консервації об'єктів основних засобів (крім } \\
\text { земельних ділянок, будинків та споруд); на дату початку по- } \\
\text { ліпшення об'єкту основних засобів: }\end{array}$} \\
\hline & на суму первісної вартості & 18 & 10 \\
\hline & $\begin{array}{l}\text { - у сумі нар } \\
\text { консервації (по }\end{array}$ & 13 & 18 \\
\hline \multicolumn{4}{|c|}{$\begin{array}{l}\text { Примітка. Таким чином, згорнуте сальдо рахунку } 18 \text { «Довгостроко- } \\
\text { ва дебіторська заборгованість та інші необоротні активи» відобра- } \\
\text { жає залишкову вартість об'єкту, що потребує поліпшення або за- } \\
\text { консервованого (крім земельних ділянок, будинків та споруд). }\end{array}$} \\
\hline 2. & $\begin{array}{l}\text { артості здійсненого по- } \\
\text { у, що збільшує майбутні } \\
\text { ди }\end{array}$ & 15 & $\begin{array}{l}20,22, \\
65,66 \\
\text { та ін. }\end{array}$ \\
\hline \multirow[t]{4}{*}{3.} & \multicolumn{3}{|c|}{$\begin{array}{l}\text { Повернення поліпшених об'єктів основних засобів в експлу- } \\
\text { атацію: }\end{array}$} \\
\hline & - на суму первісної вартості & 10 & 18 \\
\hline & $\begin{array}{l}\text { - на суму вартості проведеного поліп- } \\
\text { шення }\end{array}$ & 10 & 15 \\
\hline & $\begin{array}{l}\text { - на суму нарахованого зносу на дату } \\
\text { початку поліпшення }\end{array}$ & 18 & 13 \\
\hline \multicolumn{4}{|c|}{$\begin{array}{l}\text { Примітка. Здійснюється сторнування запису, здійсненого на дату } \\
\text { початку поліпшення об'єкту основних засобів (п. 1) та відобража- } \\
\text { ється закінчення заходів з поліпшення об'єктів (включення вартос- } \\
\text { ті робіт до первісної вартості об'єктів та, відповідно, їх подальша } \\
\text { амортизація) }\end{array}$} \\
\hline \multirow[t]{2}{*}{4.} & \multicolumn{3}{|c|}{ Ліквідація (списання) раніше законсервованих об'єктів: } \\
\hline & $\begin{array}{l}\text { - на суму залишкової вартості } \\
\text { об'єкту }\end{array}$ & 976 & 18 \\
\hline & \multicolumn{3}{|c|}{$\begin{array}{l}\text { Перекласифікація об'єктів та реалізація необоротних акти- } \\
\text { вів, утримуваних для продажу, раніше законсервованих: }\end{array}$} \\
\hline & $\begin{array}{l}\text { - відображення суми доходу від реалі- } \\
\text { зації }\end{array}$ & 361 & 712 \\
\hline & коду & 71 & 641 \\
\hline & $\begin{array}{l}\text { - собівартість реалізованих } \\
\text { (залишкова вартість об'єктів) }\end{array}$ & $\begin{array}{l}286 \\
943\end{array}$ & $\begin{array}{c}18 \\
286\end{array}$ \\
\hline
\end{tabular}

Примітка: розроблено автором на підставі [6, С. 64-66; 2] 
Переведення об'єктів основних засобів зі складу активів, що відображаються на рахунках 10, 11 до складу активів, облік яких здійснюється на рахунку 18, доцільно відображати Актом прийманняпередачі (внутрішнього переміщення) основних засобів (форма № 03-1) з одночасним вилученням (тимчасовим) із картотеки Інвентарної картки обліку основних засобів (форма № 03-6), в якій слід зробити відповідну відмітку. Узагальнення інформації вказаних первинних документів слід відобразити у Журналі 4, що ведеться за кредитом рахунків 10, 11, $12,13,14,15,18,19,35$. Для цього розділ 1 слід доповнити рядком, в якому вказати, що за дебетом вказані рахунки можуть кореспондувати з дебетом рахунку 18; розділ 2 слід відкоригувати в частині кореспонденції, що не відповідає вимогам lнструкції № 291 в частині операцій з іншими необоротними активами (забрати знак «Х» 3 перетинів рядка 5 та графи 4, рядків 1, 2, 3 та графи 5). Відомість 4.1 аналітичного обліку капітальних інвестицій доповнити рахунком 18 в частині загальної назви колонок №№ 1013.

Рахунок 18 слід деталізувати шляхом доповнення Інструкції № 291 субрахунком 184 «Необоротні активи у поліпшенні та на консервації», а субрахунку «Інші необоротні активи» присвоїти номер 185, з таким тлумаченням змісту відображуваної на них інформації:

На субрахунку 184 «Необоротні активи у поліпшенні та на консервації» ведеться облік наявності об'єктів основних засобів та інших необоротних матеріальних активів, переданих на консервацію або тимчасово вилучених з участі у господарській діяльності з метою здійснення заходів щодо їх поліпшення.

На субрахунку 185 «Інші необоротні активи» відображаються інші активи, використання яких, як очікується, неможливе протягом дванадцяти місяців з дати балансу, зокрема грошові кошти». Порядок відображення господарських операцій на субрахунках рахунку 18 узагальнено в табл. 2. 
Призначення субрахунків рахунку 18

\begin{tabular}{|c|c|c|}
\hline $\begin{array}{l}\text { Раху- } \\
\text { нок }\end{array}$ & Субрахунок & Призначення субрахунку \\
\hline \multirow{3}{*}{ 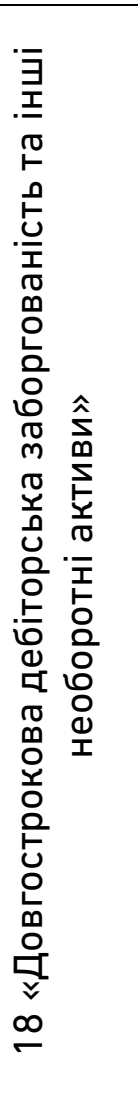 } & $\begin{array}{l}181 \text { «Заборгова- } \\
\text { ність за майно, що } \\
\text { передано у фінансо- } \\
\text { ву оренду» }\end{array}$ & $\begin{array}{l}\text { На субрахунку } 181 \text { відображаються } \\
\text { чисті інвестиції орендодавця у фі- } \\
\text { нансову оренду, визначені згідно з } \\
\text { Положенням (стандартом) бухгал- } \\
\text { терського обліку № } 14 \text { «Оренда» }\end{array}$ \\
\hline & $\begin{array}{c}182 \text { «Довгостро- } \\
\text { кові векселі одер- } \\
\text { жані» }\end{array}$ & $\begin{array}{c}\text { На субрахунку } 182 \text { ведеться облік } \\
\text { векселів, одержаних на забезпе- } \\
\text { чення довгострокової дебіторської } \\
\text { заборгованості }\end{array}$ \\
\hline & $\begin{array}{c}183 \text { «اнша дебі- } \\
\text { торська заборгова- } \\
\text { ність» }\end{array}$ & $\begin{array}{c}\text { Субрахунок } 183 \text { призначений для } \\
\text { обліку довгострокової дебіторської } \\
\text { заборгованості, яка не відобража- } \\
\text { ється на інших субрахунках рахунку } \\
18 \text { «Довгострокова дебіторська за- } \\
\text { боргованість та інші необоротні ак- } \\
\text { тиви», зокрема розрахунків з пра- } \\
\text { цівниками за виданими довгостро- } \\
\text { ковими позиками тощо, інші види } \\
\text { розрахунків }\end{array}$ \\
\hline $\begin{array}{l}\text { Paxy- } \\
\text { нок }\end{array}$ & Суб & Приз \\
\hline & $\begin{array}{c}184 \text { «Необоротні } \\
\text { активи у поліпшенні } \\
\text { та на консервації* }\end{array}$ & $\begin{array}{c}\text { На субрахунку } 184 \text { ведеться облік } \\
\text { наявності об'єктів основних засобів та } \\
\text { інших необоротних матеріальних ак- } \\
\text { тивів, переданих на консервацію або } \\
\text { тимчасово вилучених з участі у гос- } \\
\text { подарській діяльності з метою здійс- } \\
\text { нення заходів щодо їх поліпшення* }\end{array}$ \\
\hline & $\begin{array}{l}185 \text { «нші необо- } \\
\text { ротні активи» }\end{array}$ & $\begin{array}{c}\text { На субрахунку } 185 \text { відобража- } \\
\text { ються інші активи, використання } \\
\text { яких, як очікується, неможливе про- } \\
\text { тягом дванадцяти місяців з дати ба- } \\
\text { лансу, зокрема грошові кошти }\end{array}$ \\
\hline
\end{tabular}

* - запропоновано автором 
Послідовність відображення проаналізованих операцій представлено графічно (рисунок).

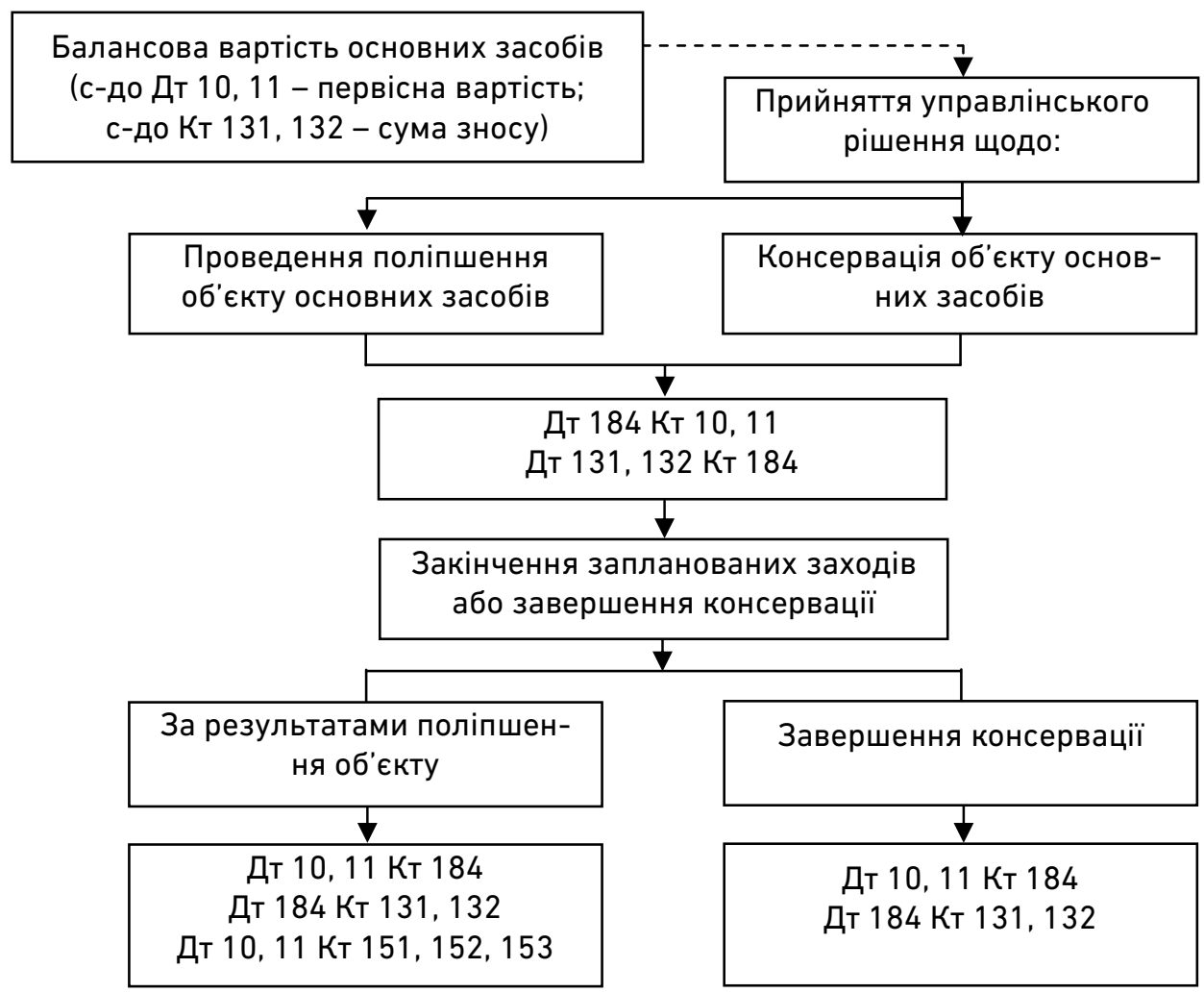

Рисунок. Послідовність відображення операцій з основними засобами за умов застосування рахунку 18 [розроблено автором]

Висновки. Отже, проведені дослідження показали, що на етапі завершення життєвого циклу інвестицій в основні засоби доцільно вести облік у розрізі передачі іншим фізичним та юридичним особам, ліквідації (списання) та інших видів вибуття із урахуванням відповідності інтересам інвестора щодо отримання/недоотримання економічної вигоди.

Резюмуючи проведені у статті дослідження слід зазначити, що результати вивчення обліку основних засобів як об'єктів реального інвестування довели необхідність відображення реальних інвестицій в основні засоби у складі статей «Основні засоби» Балансу (Звіту про фінансовий стан) (форма № 1) та у розділі II «Основні засоби» Приміток до річної фінансової звітності (форма № 5).

1. Положення (стандарт) бухгалтерського обліку 7 «Основні засоби» : наказ Міністерства фінансів України від 27.04.2000 р. №92. URL: http://zakon4.rada.gov.ua/laws/show/z0288-00. (дата звернення: 
Серія «Економічні науки»

Випуск 4(84) 2018 р.

15.05.2019). 2. Методичні рекомендації з бухгалтерського обліку основних засобів : наказ Міністерства фінансів України від 30 вересня 2003 р. № 561. URL: http://www.minfin.gov.ua/control/uk/publish/article?art_id=293623. (дата звернення: 15.05.2019). 3. Зінкевич О. В. Облік основних засобів на етапі реалізації реальних (капітальних) інвестицій. Економіка та суспільство: електронне наукове фахове видання. 2017. №9. C. 1127-1133. URL: http://www.economyandsociety.in.ua/journal-9/16-stati-9/998-zinkevich-o-v. (дата звернення: 15.05.2019). 4. Інструкція про застосування Плану рахунків бухгалтерського обліку активів, капіталу, зобов'язань і господарських операцій підприємств і організацій : наказ Міністерства фінансів України від $30 \quad$ листопада 1999 р. № $291 . \quad$ URL: http://zakon0.rada.gov.ua/laws/show/z0893-99. (дата звернення: 15.05.2019). 5. Должанський А. М., Сістук О. М. Облік операцій з консервації основних засобів. Удосконалення обліку, аналізу, аудиту і звітності у сучасних умовах глобалізаційних процесів у світовій економіці : тези виступів Другої міжнар. науково-практичної конф. м. Ужгород, 21-22 квіт. 2015 р. Ужгород, 2015. С. 80-82. 6. Зінкевич О. В. Щодо обліку стану та руху основних засобів як елементу інформаційного забезпечення аудиту. Сучасні проблеми економіки в умовах глобальної фінансової нестабільності : матеріали екон. наук. Інтернет-конф. Ч. 1. Тернопіль, 2010. С. 64-66.

\section{REFERENCES:}

1. Polozhennia (standart) bukhhalterskoho obliku 7 «0snovni zasoby» : nakaz Ministerstva finansiv Ukrainy vid 27.04.2000 r. № 92. URL: http://zakon4.rada.gov.ua/laws/show/z0288-00. (data zvernennia: 15.05.2019). 2. Metodychni rekomendatsii z bukhhalterskoho obliku osnovnykh zasobiv : nakaz Ministerstva finansiv Ukrainy vid 30 veresnia 2003 r. № 561. URL: http://www.minfin.gov.ua/control/uk/publish/article?art_id=293623. (data zvernennia: 15.05.2019). 3. Zinkevych 0. V. Oblik osnovnykh zasobiv na etapi realizatsii realnykh (kapitalnykh) investytsii. Ekonomika ta suspilstvo: elektronne naukove fakhove vydannia. 2017. № 9. S. 1127-1133. URL: http://www.economyandsociety.in.ua/journal-9/16-stati-9/998-zinkevich-o-v. (data zvernennia: 15.05.2019). 4. Instruktsiia pro zastosuvannia Planu rakhunkiv bukhhalterskoho obliku aktyviv, kapitalu, zoboviazan i hospodarskykh operatsii pidpryiemstv $\mathrm{i}$ orhanizatsii : nakaz Ministerstva finansiv Ukrainy vid 30 lystopada 1999 r. № 291. URL: http://zakon0.rada.gov.ua/laws/show/z0893-99. (data zvernennia: 15.05.2019). 5. Dolzhanskyi A. M., Sistuk O. M. Oblik operatsii z konservatsii osnovnykh zasobiv. Udoskonalennia obliku, analizu, audytu i zvitnosti u suchasnykh umovakh hlobalizatsiinykh protsesiv u svitovii ekonomitsi : tezy vystupiv Druhoi mizhnar. naukovo-praktychnoi konf. m. Uzhhorod, 21-22 kvit. 2015 r. Uzhhorod, 2015. S. 80-82. 6. Zinkevych 0. V. Shchodo obliku stanu ta rukhu osnov-nykh zasobiv yak elementu informatsiinoho zabezpechennia audytu. Suchasni problemy ekonomiky $v$ umovakh hlobalnoi finansovoi nestabilnosti : materialy ekon. nauk. Internet-konf. Ch. 1. Ternopil, 2010. S. 64-66.

Рецензент: д.е.н., доцент Осадча О. О. (НУВГП) 
Zinkevych 0. V., Candidate of Economics (Ph.D.), Associated Professor (National University of Water and Environmental Engineering, Rivne)

\section{ACCOUNTING OF FIXED ASSETS AT THE STAGE OF COMPLETING THE LIFE CYCLE OF INVESTMENTS IN THEM}

The article is devoted to the research of the accounting methodics of fixed assets at the stage of completing of investments in them. An existing approach to the accounting of business operations for the retirement of fixed assets in connection with their improvement or conservation is analyzed and suggestions regarding the reflection of such operations in the accounts, taking into account the directions and reasons for the retirement are made. The use of a separate subaccount 184 "Non-current assets in improvement and conservation" for the account 18 "Long-term receivables and other non-current assets" is proposed. The recommended correspondence of accounts with the use of the proposed subaccount is formed. The changes concerning the details of the primary accounting documents and accounting records used in the display of business operations for the disposal of non-current assets and their subsequent return are described.

Keywords: fixed assets, other non-current tangible assets, retirement of non-current assets, accounting, re-classification of assets.

Зинкевич О. В., к.э.н., доцент (Национальный университет водного хозяйства и природопользования, г. Ровно)

УЧЕТ ОСНОВНЫХ СРЕДСТВ НА ЭТАПЕ ЗАВЕРШЕНИЯ ЖИЗНЕННОГО ЦИКЛА ИНВЕСТИЦИЙ В НИХ

Статья посвящена рассмотрению методики учета основных средств на этапе завершения инвестиций в них. Проанализирован существующий подход и поданы предложения относительно отображения таких операций на бухгалтерских счетах с учетом направлений и причин выбытия. Сформирована рекомендованная корреспонденция счетов. Описаны изменения, которые коснутся реквизитов первичных бухгалтерских документов и регистров, используемых при отображении хозяйственных операций выбытия необоротных активов и их последующего возвращения.

Ключевые слова: основные средства, прочие необоротные материальные активы, выбытие необоротных активов, учет, переклассификация активов. 